\title{
構造要素の衝突圧壊強度に関する基礎的研究
}

\section{（その 2）円筒殸の非軸対称圧壊実験と有限要素解析}

$\begin{array}{lllll}\text { 正員 都 井 } & \text { 裕* 正員 弓 削 康 平** } \\ \text { 正員 小 畑 和 彦* } & & & \end{array}$

Basic Studies on the Crashworthiness of Structural Elements

Part 2 Non-axisymmetric crush tests of circular cylinders and finite element analysis

by Yutaka Toi, Member

Kouhei Yuge, Member

Kazuhiko Obata, Member

\section{Summary}

The non-axisymmetric crush tests were conducted for 11 mild steel cylinders with different $R / t$ ratios, and the obtained results were compared with the theoretical, numerical and other experimental results from various points of view. The conclusions can be summarized as follows :

(1) The plastic buckling loads due to Gerard's theory agree well with the maximum loads obtained in the present experiments.

(2) As for the relation between the radius-to-thickness ratio and the circumferential wavenumber in the non-axisymmetric crushing mode, the validity of the existing solutions given by one of authors was confirmed.

(3) Magee's empirical formula for the mean crushing strength is in good agreement with the present expermental results.

(4) The nonlinear finite element code developed in the previous report gave improved solutions for the mean crushing stresses in comparison with the existing rigid-plastic solutions, which are in good agreement with the experimental results except for the case of relatively thick-walled cylinders.

(5) The actual complicated crushing processes accompanied with traveling hinge lines were successfully simulated by the present finite element code.

\section{1 序}

著者らは近年, 軸圧縮荷重を受ける円筒殼の非軸対称 圧壊問題をいくつかの研究で採り上げた。すなわち，非 軸対称圧壊モードに関しては, 半径・肉厚比 $(R / t$ と記 す) と周方向波数 ( $n$ と記す) の関係を, 弾性座屈理論 および低自由度モデルによる塑性座屈シミュレーション により検討した1)。平均圧壊荷重に関しては, 剛塑性理 論解の再検討 2), 剛体・ばねモデルによるシミュレー ション3), および低次要素による有限要素解析)を実施 した。これらの研究を通じ, 軸圧縮荷重下の円筒殸の非 軸対称圧壊現象について，凡そ把握の見込みが立ったの

* 東京大学生産技術研究所

** 東京大学大学院
で, 本研究においては, $R / t$ の異なる 11 体の鋼管試験 体を用いた圧壊実験を実施し，これまでの研究成果との 総合的な比較検討を試みた。

以下, 第 2 章では実験結果の概要を説明し，第 3 章で は塑性座屈荷重, 非軸対称圧壊モードおよび平均圧壊荷 重の各項目に関し，簡単な考察を加え，第 4 章では前報 で開発した有限要素コードによる圧壊解析結果を本実験 結果と比較する。第 5 章は結言である。

\section{2 円筒鋼管の圧壞荚験}

JIS 規格による配管用炭素鋼鋼管 STPT 38 より製作 した 11 体の鋼管試験体に対し, 軸圧縮荷重による压壊 実験を実施した。本章では材料試験結果を含めて実験結 果の概要を述べる。 


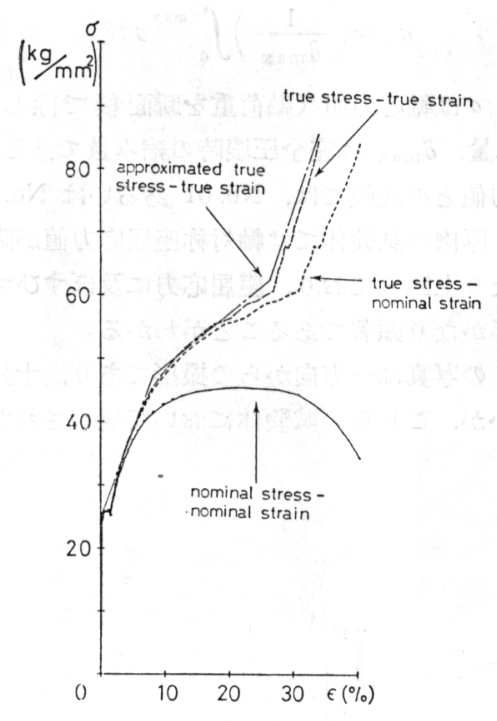

Fig. 1 Stress-strain curves obtained from uniaxial tensile test

\section{1 材料試験結果}

圧壊実験に使用した鋼管の一部から作成した丸棒材料 試験片を用いて, 引張り試験を実施した。本材料試験に おいては, 荷重, 標点間距離㧍よびくびれ (necking) を生じた部分の直径,の各項目に関し計測した。得られ た応力・ひずみ曲線をFig. 1 に示す。図中には, 公称 応力・公称ひずみ, 真応力・公称ひずみ, 特よび真応 力・真ひずみ（対数ひずみ）関係が示されており, 真応 力値は荷重值をくびれ部断面積で除すことにより計算し た。本材料試験により公称応力・公称ひずみ関係に対し 定められた材料定数は以下の之おりである。

ヤング率: $E=2.1 \times 10^{4}\left(\mathrm{~kg} / \mathrm{mm}^{2}\right)$

降伏応力: $\sigma_{y}=25.55\left(\mathrm{~kg} / \mathrm{mm}^{2}\right)$

引張り強度 : $\sigma_{u}=45.4\left(\mathrm{~kg} / \mathrm{mm}^{2}\right)$

第 4 章で実施する有限要素解析は, updated Kirchhoff 応力および updated Green ひずみを用いた updated Lagrangian formulation に基づいて和り, 材料の構成 式としては真応力・真ひずみ関係を入力しなければなら ない。実際の計算に際しては, 材料試験で計測された真 応力・真ひずみ曲線を Fig. 1 亿示すように 4 直線近似 で表現し，相当応力・相当ひずみ関係として入力した。 降伏応力に達するまでは上記の公称応力・公称ひずみ関 係之同様であり, 降伏後の接線係数値は以下のように定 めた。

$$
\begin{aligned}
& E_{t}=0.013 \mathrm{E}(25.55<\sigma<47.40) \\
& E_{t}=0.004 \mathrm{E}(47.40<\sigma<62.50) \\
& E_{t}=0.014 \mathrm{E}(62.50<\sigma)
\end{aligned}
$$

\section{2 円筒鋼管の圧壊実験結果}

圧壞実験に用いた 11 体の鋼管試験体の寸法を Table
Table 1 Dimensions of test specimens

\begin{tabular}{|c|c|c|c|c|}
\hline No. & $\begin{array}{c}\mathrm{R} \\
(\mathrm{m})\end{array}$ & $\begin{array}{c}\mathrm{t} \\
(\mathrm{mI})\end{array}$ & $\mathrm{R} / \mathrm{t}$ & $\begin{array}{c}\text { Area } \\
\left(\mathrm{m}^{2}\right)\end{array}$ \\
\hline \hline 01 & 57.21 & 3.380 & 16.92 & 1215 \\
\hline 11 & 56.94 & 2.825 & 20.15 & 1010 \\
\hline 21 & 56.45 & 1.911 & 29.54 & 677.8 \\
\hline 31 & 56.23 & 1.434 & 39.21 & 506.6 \\
\hline 42 & 56.09 & 1.124 & 49.90 & 396.1 \\
\hline 51 & 55.98 & 0.970 & 57.71 & 341.1 \\
\hline 61 & 55.92 & 0.820 & 68.20 & 288.1 \\
\hline 71 & 55.87 & 0.732 & 76.28 & 257.1 \\
\hline 81 & 55.85 & 0.657 & 85.01 & 230.5 \\
\hline 91 & 55.81 & 0.553 & 100.9 & 193.9 \\
\hline 101 & 55.70 & 0.309 & 180.3 & 108.1 \\
\hline
\end{tabular}

1 亿示す。これらの鋼管試験体はいずれも単一の長尺鋼 管 $(12 \mathrm{~m})$ を所要の長さに切断し, 旋盤により内側を切 削して所定の肉厚に加工したものである。 $R / t$ は 17 か ら 180 の範囲に分布しており, 長さは $250 \mathrm{~mm}$ に統一 した。

試験体は 50 ton 疲労試験機の鋳鉄製の加圧盤間に据 え置かれ, 準静的に圧縮された (Fig. 2 を参照)。実験 に際しては, 荷重と軸方向縮み量のみを計測し, 試験体 中央部には偏心荷重のチェックのためにひずみゲージを 貼付したが，特に問題となるような偏心荷重は見られな かった。

Fig. 3 亿全試験体の軸応力・縮み量曲線, Fig. 4 には 代表的な試験体 4 体（No. 11, 51, 61, 91）の圧壊過程を

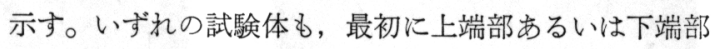

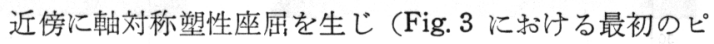
一ク荷重に対応する), 続いて非軸対称座屈モードに分 岐し, 以後, 端から順次, 非軸対称モードの発生・成

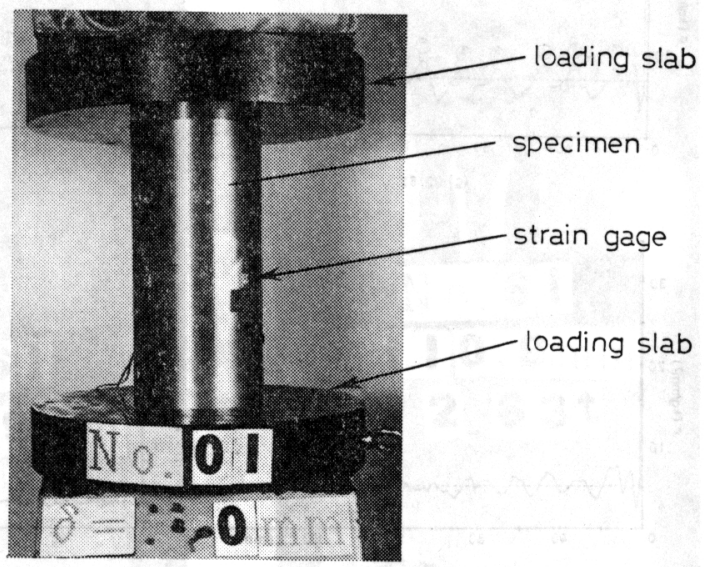

Fig. 2 Crush test of a circular cylindrical shell under axial loading 
長・圧壊を繰り返すいわゆる逐次座屈 (progressive buckling）の現象を呈した。

Fig. 3 に拈ける数字（1)，(2)など）は，非軸対称圧壊 の軸方向半波長分の進展ごとに生ずるピーク荷重を表わ しており，X印は他端部の影響によりそれまでの規則的 な非軸対称モードが崩れたことを意味する。非軸対称圧 壊時のピーク荷重は軸対称塑性座屈荷重に相当する最初 のピーク荷重よりかなり低い值であり，この差は薄肉鋼 管ほど顕著である。Fig. 3 には，次式で計算された平均 圧壊応力値も合わせて示されている。

$$
\sigma_{m}=\left(\frac{1}{\delta_{\max }}\right) \int_{0}^{\delta_{\max }} \sigma d \delta
$$

ここに，のは軸応力値（軸荷重を断面積で除した值）， $\delta$ は縮み量, $\delta_{\max }$ は完全圧壊時の縮み量である。また, 降伏応力值との比較では, No.01 あるいは No. 11 など のかなり厚肉の試験体では軸対称座屈応力值が降伏応力 值をかなり上回っており，座屈応力に及ぼすひずみ硬化 の影響がかなり顕著であることがわかる。

Fig. 4 の写真は一方向からの撮影であり, 十分に判別 できないが，これらの試駼体において観察された非軸対

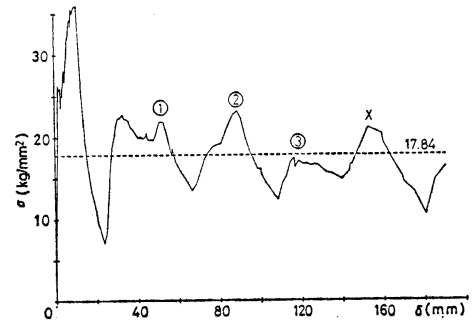

(a) $N 0.01$
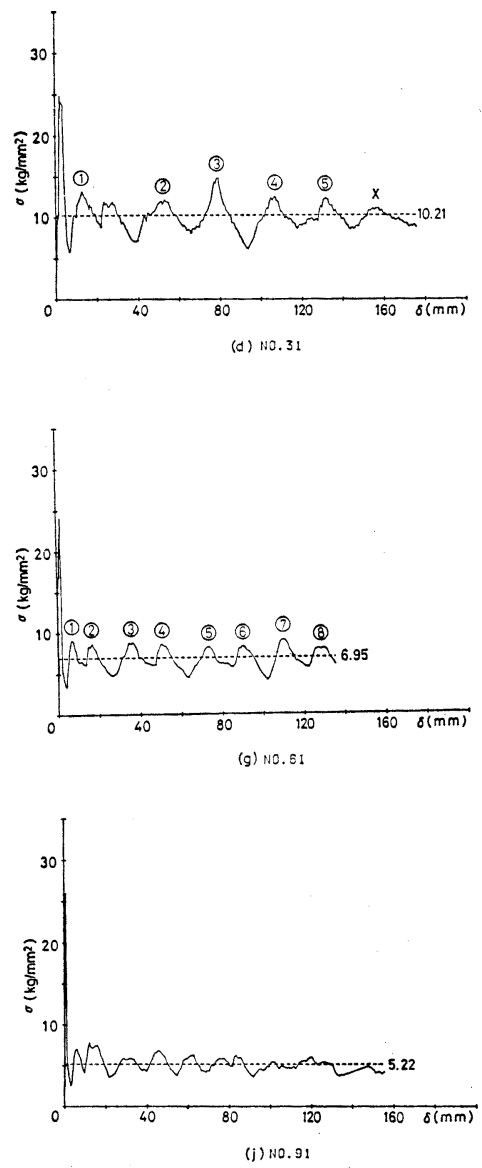

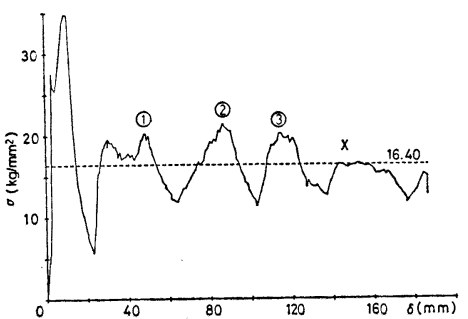

(b) No.11
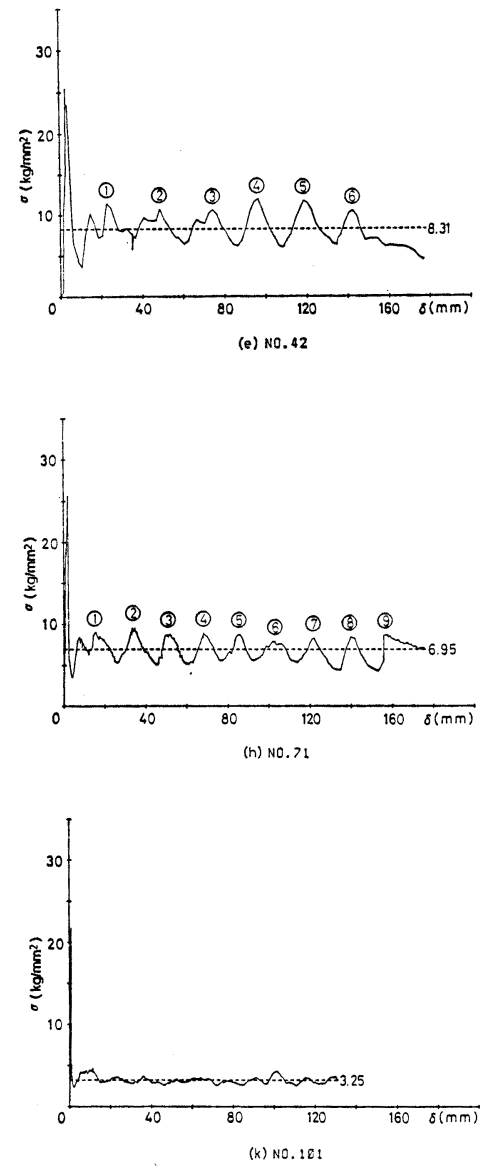
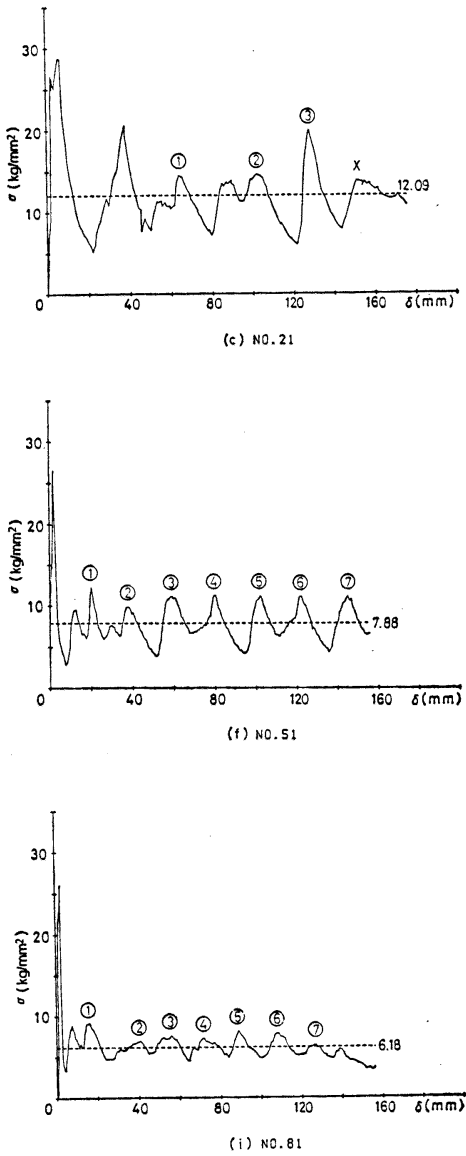

(i) N0.81

Fig. 3 Axial load-shortening curves (experiments) 

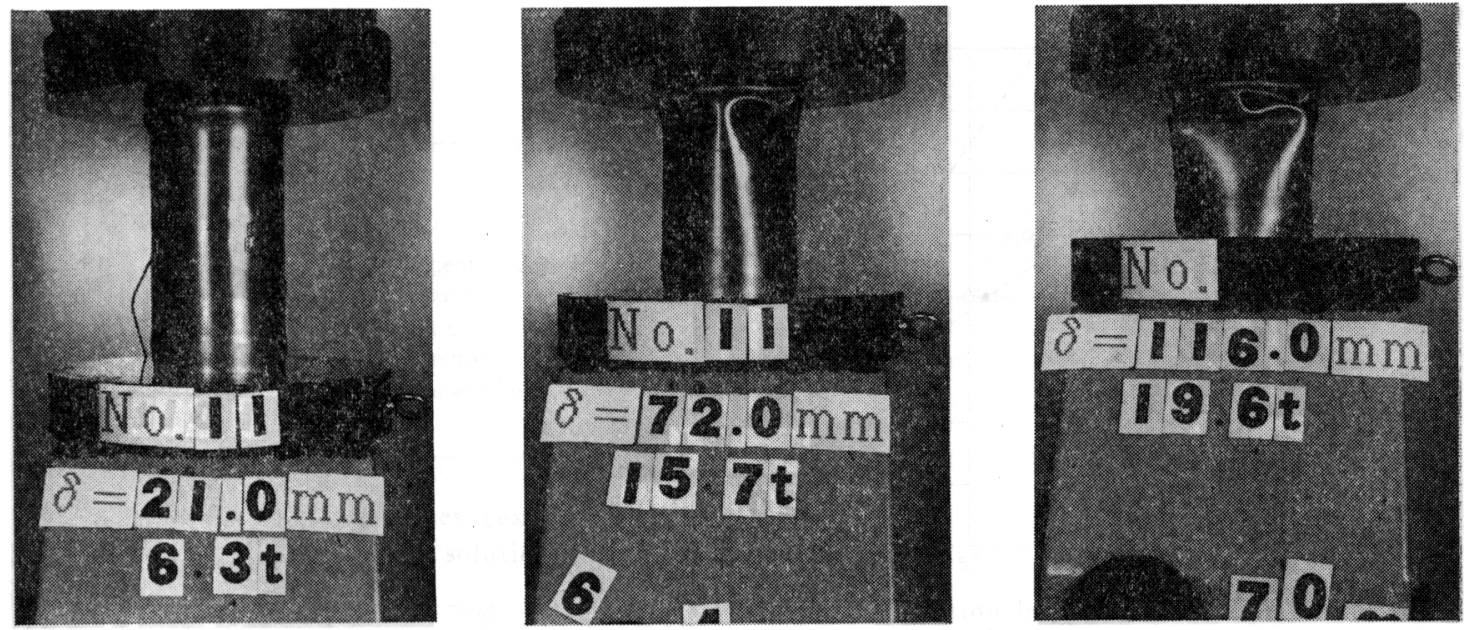

(a) No. $11(n=3)$
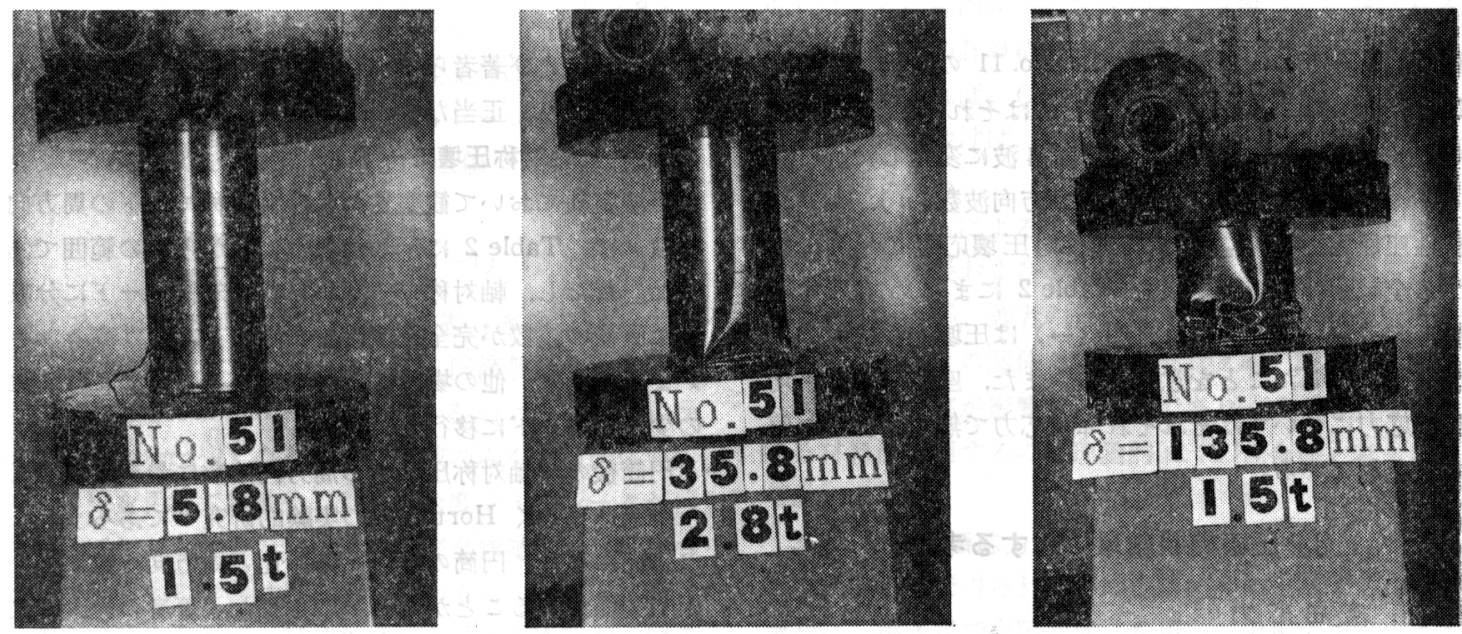

(b) No. $51(n=4)$
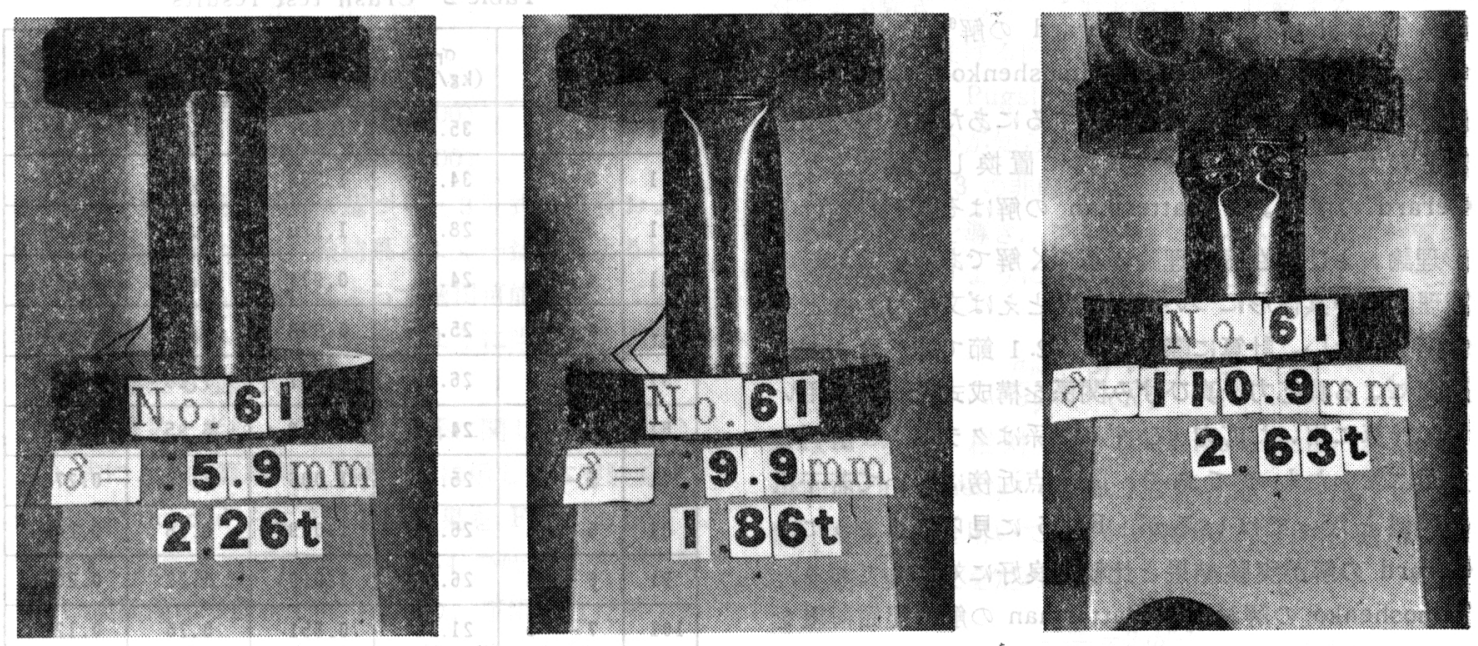

(c) No. $61(n=5)$ 

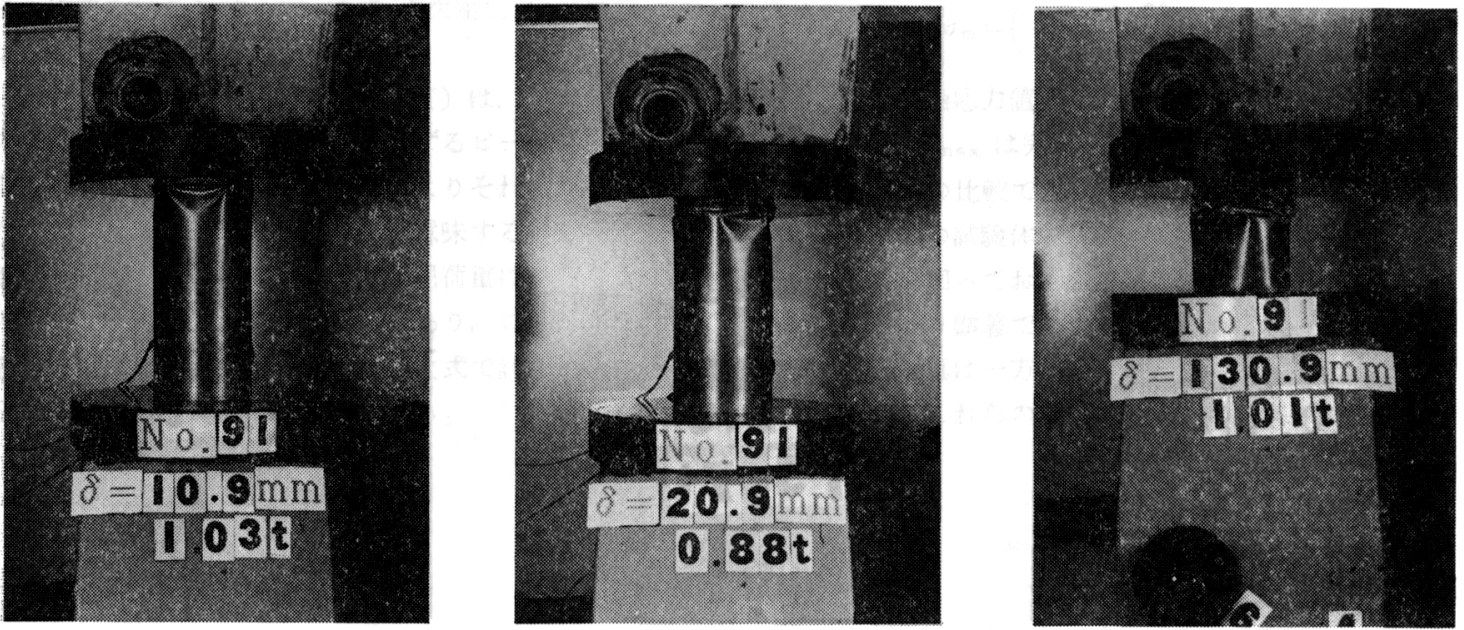

(d) No.91 ( $n=6)$

Fig. 4 Experimental crushing processes

称圧壊モードの周方向波数は, No. 11 の試験体で 3 , No. 51 で 4, No. 61 と No. 91 ではそれぞれ圧壊初期 の 5 波㟧よび 6 波から最終的には 4 波に変化した。

非軸対称圧壞モードにお汸る周方向波数 $(n)$, 軸対称 塑性座屈応力 $\left(\sigma_{\max }\right)$ および平均圧壊応力 $\left(\sigma_{m}\right)$ に関 する全試験体の実験結果を Table 2 にまとめて示す。 周方向波数の欄における矢印 ( 波数が変化したことを意味する。また，座屈応力と平均 圧壞応力についてはそれぞれ降伏応力で無次元化した值 も示されている。

\section{3 圧壊実験結果に対する考察}

\section{1 座屈応力}

圧壊実験の結果得られた最大応力値を軸対称塑性座屈 応力に対する 4 種の理論解, すなわち, 接線係数理論 解, Timoshenko の解 ${ }^{5)}$, Gerard の解 ${ }^{6)}$ おょび Batterman の解 ${ }^{7)}$ と比較した。Timoshenko の解は, 弾性 座屈荷重に接線係数理論を適用するにあたり，曲げ剛性 部分のヤング率のみを接線係数に置換した解であり,

Gerard の解および Batterman の解はそれぞれ塑性変 形理論および塑性流れ理論に基づく解である。これらの 諸理論解の具体形については，たとえば文献 1)などを 参照されたい。計算に際しては，2.1 節で述べた 4 直線 近似による真応力・真ひずみ関係を構成式として用い た。計算に用いた応力・ひずみ関係はクラッシニ解析を 念頭においたものであり，降伏点近傍において若干粗 い近似となってはいるが，Fig. 5 に見られるように， Gerard の解が実験結果と比較的良好に対応しており, Timoshenko の解および Batterman の解は座屈荷重を 過大に評価している。この結論は Sobel と Newman
の研究 ${ }^{8)}$ および著者らの別途実施した研究 ${ }^{9)}$ の結果とも 一致しており，正当なものと考えられる。

\section{2 非軸対称圧壊モード}

圧噮実験において観察された非軸対称モードの周方向 波数 $n$ は, Table 2 に示したように 3 から 7 の範囲であ つた。ただし, 軸対称モードから非軸対称モードに分岐 した直後の波数が完全圧壊時まで継続したのは高々 $n=$ 4 までであり, 他の場合は圧壊の進展とともにより波数 の少ないモードに移行した。

円筒殼の非軸対称圧壊時の周方向波数に最初に着目し た研究は恐らく Horton らの実験的研究10)であろう。こ の研究により, 円筒の半径・肉厚比と周方向波数に強い 相関関係があることが明らかにされた。著者の一人は文 献 1) において, 弾性座屈理論に基づき, 周方向波数 $n$

Table 2 Crush test results

\begin{tabular}{|c|l|c|c|c|c|}
\hline Ho. & $\mathrm{n}$ & $\begin{array}{c}\sigma_{\max } \\
\left(\mathrm{kg} / \mathrm{mm}^{2}\right)\end{array}$ & \begin{tabular}{c}
$\sigma_{\max }$ \\
\hline$\sigma_{\mathrm{y}}$
\end{tabular} & $\begin{array}{c}\sigma_{\mathrm{m}} \\
\left(\mathrm{kg} / \mathrm{mm}^{2}\right)\end{array}$ & $\sigma_{\mathrm{m}} / \sigma_{\mathrm{y}}$ \\
\hline 01 & 3 & 35.95 & 1.407 & 17.84 & 0.698 \\
\hline 11 & 3 & 34.20 & 1.338 & 16.40 & 0.642 \\
\hline 21 & 3 & 28.70 & 1.128 & 12.09 & 0.473 \\
\hline 31 & $4 \rightarrow 3$ & 24.90 & 0.974 & 10.21 & 0.400 \\
\hline 42 & $4 \rightarrow 3$ & 25.50 & 0.998 & 8.31 & 0.325 \\
\hline 51 & 4 & 26.50 & 1.037 & 7.88 & 0.308 \\
\hline 61 & $5 \rightarrow 4$ & 24.10 & 0.943 & 5.95 & 0.272 \\
\hline 71 & $5 \rightarrow 4$ & 25.71 & 1.006 & 6.95 & 0.272 \\
\hline 81 & $6 \rightarrow 4$ & 26.05 & 1.019 & 6.18 & 0.242 \\
\hline 91 & $6 \rightarrow 4$ & 26.06 & 1.019 & 5.22 & 0.204 \\
\hline 101 & $7 \rightarrow 5$ & 21.76 & 0.851 & 3.25 & 0.127 \\
\hline
\end{tabular}




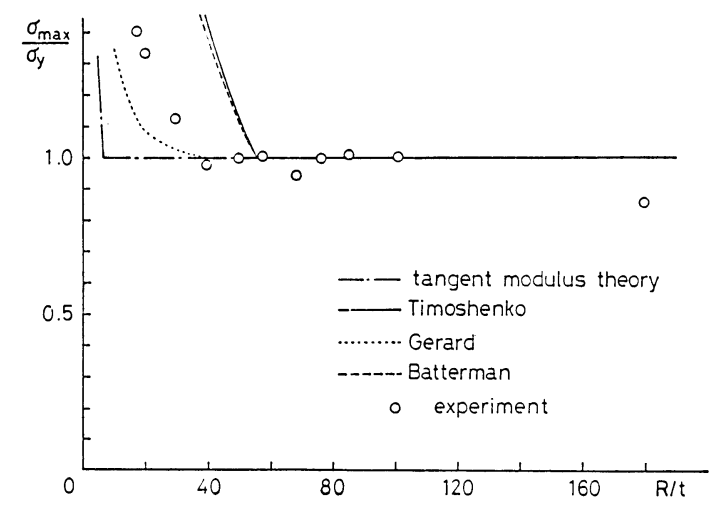

Fig. 5 Plastic buckling stresses (experimental results and theoretical solutions)

で巫屈する円筒の半径・肉厚比の下限値として, 次式で 計算される $(R / t)_{e l}$ を導いた。

$$
\left(\frac{R}{t}\right)_{e l}=\frac{2 n^{2}}{\sqrt{3\left(1-\nu^{2}\right)}}
$$

また，上式を導く際の考方方を塑性変形に伴ら場合にも 適用し，炭素鋼鋼管に対するシミュレーション結果 ${ }^{1)} に$ 基づいて, 次式で計算される下限值 $(R / t)_{p l}$ を与え た2)。

$$
\left(\frac{R}{t}\right)_{p l}=0.548 \sqrt{\frac{E}{\sigma_{y}}}(n-1)
$$

（4）式の係数値は数値計算結果に基づき決定されてい るが，数值シミニレータとしては，円筒殼の非軸対称座 屈モード (diamond pattern あるいは Yoshimura buckle pattern ${ }^{11)}$ ) の基本周期領域のみを平板剛体要素 モデル12)を用いて離散化した 9 自由度シミュレータが使 用されており，計算の際，材料は完全弾塑性体と仮定さ れひずみ硬化の影響は無視されている。

類似の試みとして，Mahmood らによる次式を上げる ことがでさる13)。

ここに,

$$
\frac{R}{t}=\frac{5.2 n^{2}}{\sqrt{\left(1-\nu^{\prime 2}\right)}}
$$

$$
\begin{aligned}
& \nu^{\prime}=0.3 \quad(R / t \geqq 100) \\
& \nu^{\prime}=0.5 \quad(R / t<100)
\end{aligned}
$$

この式は, 弾性座屈理論に基づく（3）式の係数および ポアソン比の值を圧壊実験結果とよく一致するように修 正して定められた，材料によらず適用可能とされている 半実験式であり，（3），(4) 式のように半径・肉厚比の 下限值を与える理論式ではない。

周方向波数と半径・肉厚比の関係に関し, (3), (4), (5) 式による計算結果, Table 2 に示した本実験結果, および Mahmood らによる実験結果を Fig. 6 で比較し た。（4）式による $R / t$ は $n=2 \sim 4$ の低次モードに関 しては実験值の一部を上回っており，下限值となってい ないが,これは（4）式を定める際, 完全弾塑性体を仮

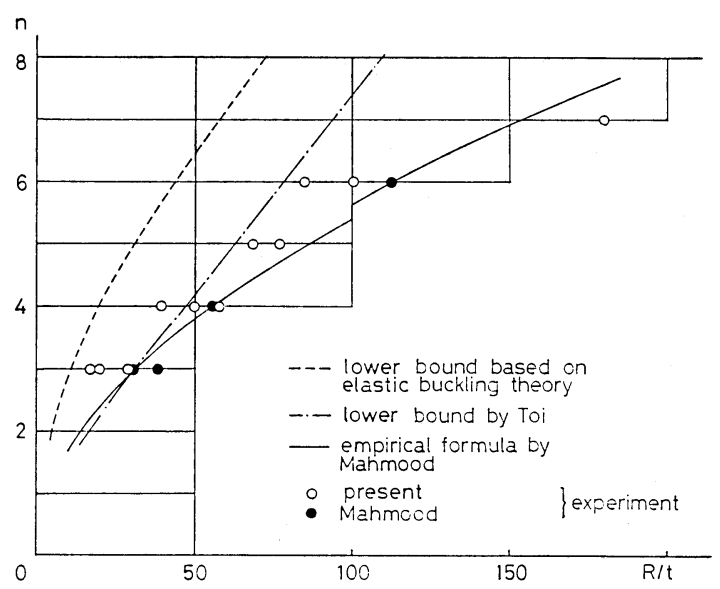

Fig. 6 Relation between circumferential wavenumber and radius-to-thickness ratio

定したことに起因する。すなわち，文献 1）に新汁るス テンレス鋼管の計算結果から判断して, ひずみ硬化ま考 慮して計算すれば, $(R / t)_{p l}$ の值は低下する可能性が高 い。その点を除けば，（3）式怙よび（4）式はほぼ妥 当と判断される。

Mahmood らによる（5）式は半実験式であるため, 自らの実験結果および著者らの実験結果と比較的良好に 対応しているが，著者の一人による文献 1）の解析によ れば, $R / t$ と $n$ の関係に対し, ヤング率, 降伏応力およ びひずみ硬化率が影響するはずであり, 式 (5) をあら ゆる材料に適用するのは理論的には不合理と考えられ る。

\section{3 平均圧壊応力}

本圧壊実験で得られた平均圧壊応力値に関する詳細な 解析は, 第 4 章で有限要素法を用いて実施するが，ここ ではそれに先立ち, 本実験結果を既存の平均圧壊応力に 対する実験式（あるいは半実験式）と比較する。

軸圧縮力を受ける円筒鋼管の平均圧壊応力に関する実 験式としては, Pugsley $5^{15)}$, Magee $5^{14)}$, Mahmood ら ${ }^{13)}$ によるものが知られている。Pugsleyらは㓮塑性解 析により, $n=3$ の非軸対称圧壊モードに対する平均圧 壊応力算定式を導き, アルミニウム/ステンレス鋼管の 実験結果に合うように係数值を修正して次式を与えてい る。

$$
\frac{\sigma_{m}}{\sigma_{y}}=5\left(\frac{t}{R}\right)+0.13
$$

Magee らは, 相対密度 (relative density あるいは structural density) $\phi$, および降伏応力の代わりに引 張り強度 $\sigma_{u}$ を用いて, 材料の種類によらず, 適用可能 な次式の実験式を定めている。

$$
\frac{\sigma_{m}}{\sigma_{u}}=2 \phi^{0.7}
$$


ここに,

$$
\phi=\frac{2 \pi R t}{\pi R^{2}}=\frac{2 t}{R}
$$

(7) 式の両辺を $\sigma_{y}$ で除すと次式を得る。

$$
\frac{\sigma_{m}}{\sigma_{y}}=2\left(\frac{2 t}{R}\right)^{0.7}\left(\frac{\sigma_{u}}{\sigma_{y}}\right)
$$

また, Mahmood らは材料定数の異なる炭素鋼鋼管に対 する圧壊実験結果に基づき, 次式の平均圧壊応力算定式 を与えている。

$$
\frac{\sigma_{m}}{\sigma_{y}}=\sqrt{\frac{r E(t / R)}{\sigma_{y}}}
$$

ここに, $\gamma$ は $R / t$ に依存する無次元パラメータであり, ひずみ硬化の影響を表わしていると解釈できる。

(6) 式，(7b) 式および (8) 式により計算される 平均圧壊応力值を本実験結果と比較して Fig. 7 に示す。 Pugsley らの算定式は，本実験と異なる材料の円筒鋼管 に対する実験結果に基づいて定められているので本実験 結果と若干の隔たりがあるのは当然であるう。他の 2 式 については, Magee らによる算定式の方が本実験結果 とは良好に対応していると判断される。

\section{4 円筒鋼管の有限要素圧壊解析}

本章では, 前報4)で開発した薄肉鋼構造要素の超大変 形圧壊解析用有限要素コードを用いて, 本圧壊実験に対 する数值計算を行い，実験結果と対比する。

\section{1 解 析 法}

本解析に使用した有限要素コードの主要な特徵は, 次 数低減積分法に基づく双一次四辺形シェル要素を一点積 分要素（すなわち定モーメント要素）として用いている こと, updated Lagrangian approach による增分理論 飞従っていること, 層分割法 (layered approach) によ り塑性変形を考慮していることなどであるが, 解析アル ゴリズムの詳細については前報を参照されたい。

前報での解析と同様に, 非軸対称圧壊モードに掠ける 基本周期領域（周方向にも軸方向にも半波長の範囲）の

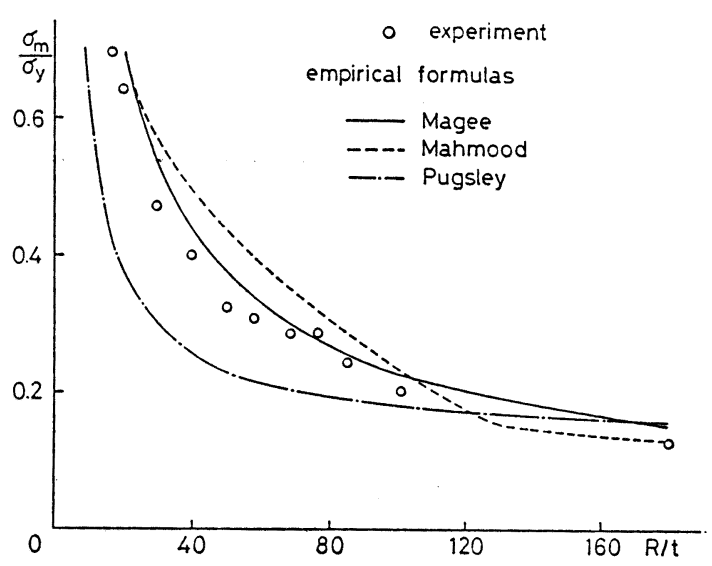

Fig. 7 Mean crushing stresses (experimental results and empirical formulas)

みを解析対象とし，周辺に対称条件を課した上で，軸方 向の強制変位を加兄压壊した。周方向波数は本圧壊実験 で観察された值（压壤過程で変化した場合については初 期値）を入力し，軸方向波長は周方向波長と等しいと仮 定した(この半波長值を $L$ とす)。材料定数としては, 2.1 節で述べた 4 直線近似による真応力・真ひずみ関係 を用いた。

解析対称領域を $7 \times 7$ の正方形メッシュに分割し, (2) 式の $\delta_{\max }$ としては軸方向半波長の $70 \%$ の值を 仮定した。この值の根拠として，一般に円筒鋼管の有効

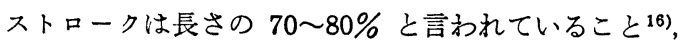
および本有限要素解析の結果によると最初に円筒壁面間 の接触が起こるのは半波長値の $60 \%$ 程度潰れた時点で あること，の 2 点を上げることができる。要した計算時 間は，增分ステップ数約 170 (各ステップ1〜2回の反 復収束計算を含む) に対し，東大大型計算センターの HITAC-M $680 \mathrm{H}$ を用いた場合約 8 分であった。

\section{2 平均圧壊荷重に関する解析結果}

計算された全試験体（No.101 を除く）に対する軸応 力・縮み量曲線を Fig. 8 に示す。周方向波数の多い高

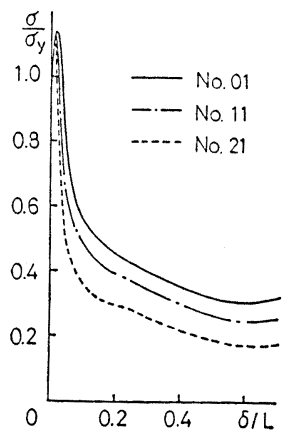

(a) $n=3$

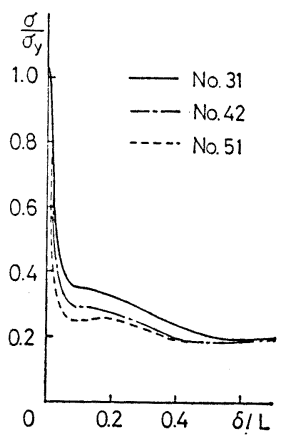

(b) $n=4$

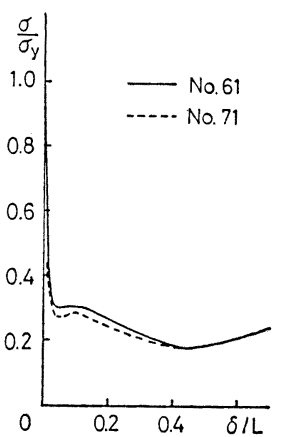

(c) $n=5$

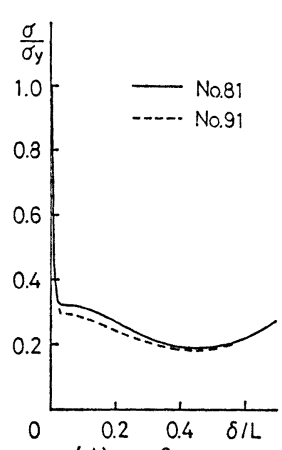

(d) $n=6$

Fig. 8 Axial load-shortening curves (finite element results) 


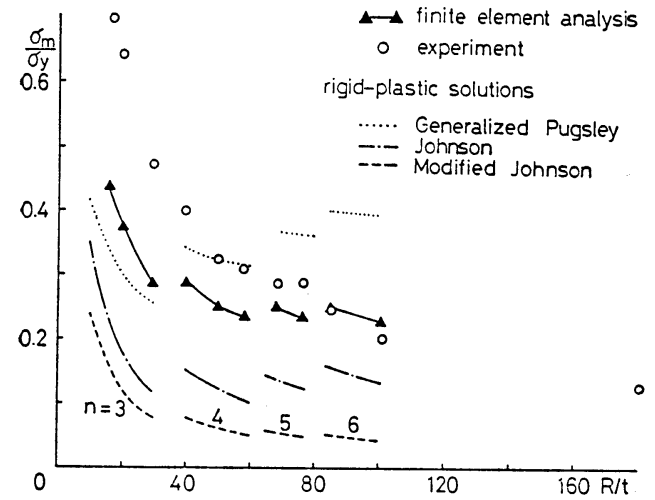

Fig. 9 Mean crushing stresses (experimental results, finite element results and rigidplastic solutions)

次モードになるほど, 最大応力後の荷重の低下は急激で あることがわかる。

Fig. 8 の軸応力・縮み量曲線から (2) 式を用いて算定 した平均圧壞応力値と本圧壊実験結果との比較を Fig. 9 に示す。有限要素解析結果は $R / t$ が $60 \sim 100$ 程度の円 筒鋼管に対しては，実験結果と良好に対応しているが， $R / t$ が小さくなるほど, すなわち厚肉となるほど実験值 との差が拡大する傾向が読み取れる。この相違の主要因 として，「薄肉」仮定の限界を上げることができる。す なわち本解析は, 面外せん断変形の影響は考慮している ものの, 薄肉シェル要素による解析であり, $R / t$ がある 程度以上小さい厚肉円筒鋼管に適用すると無視できない 誤差を生む可能性がある。特に, クラッシュ問題の場合 は, 局所的に極めて大きな变形を伴うので, 線形解析あ るいは一般の最終強度解析と比較して, 薄肉理論の適用 範囲が相当狭まる可能性がある。したがって, 定量的精 度をさらに追及するのであれば， 3 次元的な解析が要求 されることになる。

しかしながら，図中に参考のために示した三種類の剛 塑性理論解析解, 寸なわち文献 2) において考察を加え た一般化 Pugsley 解 ${ }^{2}$, Johnson 解 ${ }^{17)}$, 修正 Johnson
解 ${ }^{2)}$ と比較すると本有限要素解析は大幅に改善された解 を与えていると判断できる。

\section{3 圧壊変形過程に関する結果}

Fig. 10 と Fig. 11 に圧壊変形過程に関する解析結果 を示す。

説明の順序が逆になるが，Fig. 11 は No. 01，42, 61， 81 の試験体の圧壊変形過程を示しており，周方向波数 はそれぞれ 3 波， 4 波，5波，6波である。これらの図 は基本周期領域に対する解析結果を対称性を利用して反 転連結することにより描いている。いずれる実験で生ず る複雑な圧壊変形モードを忠実にシミュレートしてい る。

Fig. 10 は, No. 81 の試験体に対し, 基本周期領域の 横たわみに関する等高線図を描いたものである。（a） 図は初期たわみ，（b）困は座屈直後のたわみ，（c）図 は完全圧壊時のたわみを表わしている。この図を見る 之, 座屈直後に $45^{\circ}$ の角度で生じたヒンジライン（図 中, 破線で示す) が徐々に水平に近くなり，完全圧壊時 には剛塑性理論解析においてしばしば仮定されている $\pi / 2 n$ (この場合は $n=6$ なので $15^{\circ}$ ) の角度に近い傾 きとなっていることが明らかである。剛塑性理論解析に おいてはこのようなとンジラインの移動が考慮されてお らず，このここる剛塑性解析解の精度を大きく損なら一 因となっている。このような複雑な圧壊変形の時々刻々 の進展過程を再現し得ることは本解析のような多自由度 シミュレーションの最大の利点の一つである。

\section{5 結言}

本研究では, 構造要素の衝突圧壊強度に関する基礎的 研究の第 2 報として, 軸荷重を受ける円筒凯の非軸対称 圧壊問題に対し，11 体の炭素鋼鋼管を用いた圧壊実験 を実施し，実験結果を著者ら，および既存の他の研究結 果と比較しながら，種々の観点から考察を加えた。結論 を要約すると以下のとおりである。

（1）塑性座屈荷重值に関しては, Gerard の解が実

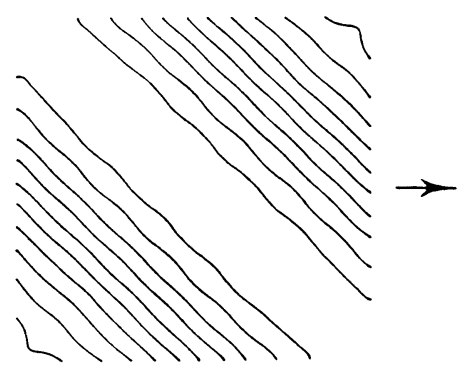

(a) initial deflection $(\delta=0)$

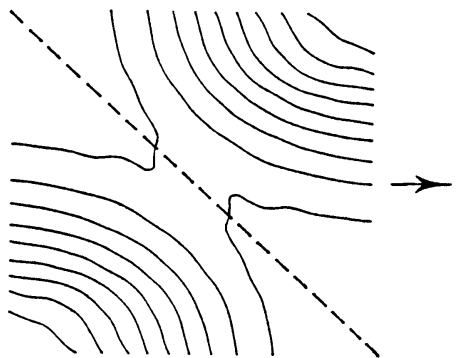

(b) initial buckling state $(\delta=0.04 \mathrm{~L})$

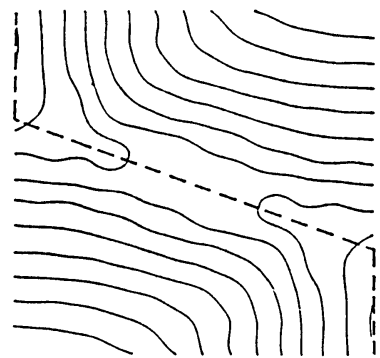

(c) completely crushed state $(\delta=0.7 \mathrm{~L})$

Fig. 10 Calculated contours for lateral deflection in No. 81 test specimen 


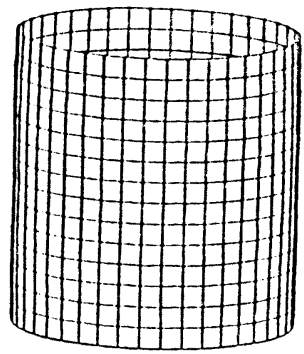

$\delta / 1=0$

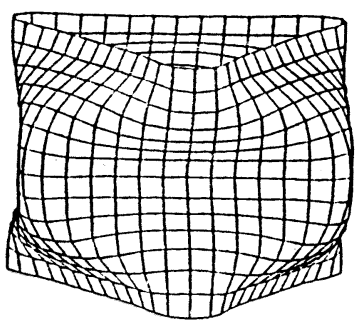

0.221

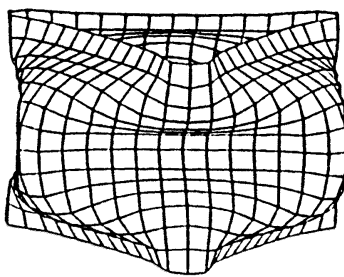

0.311

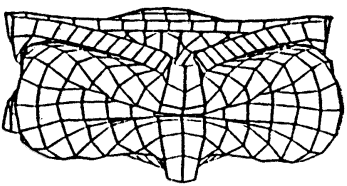

0.630

(a) No. $01(n=3)$

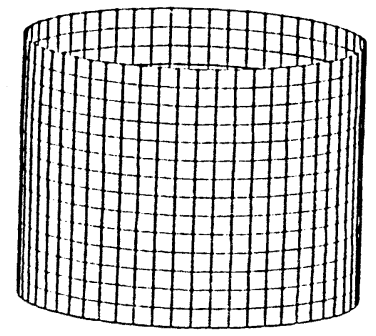

$\delta / 1=0$

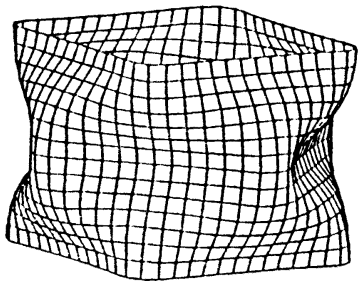

0.098

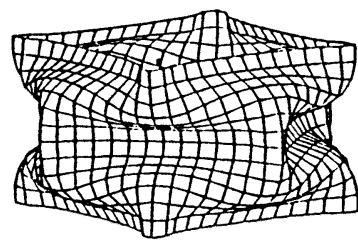

0.293

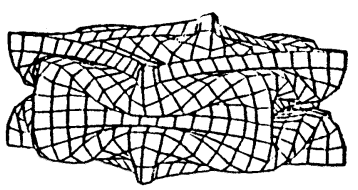

0.534

(b) No. $42(n=4)$

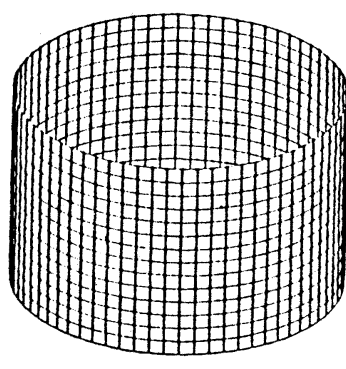

$\delta / \mathrm{L}=0$

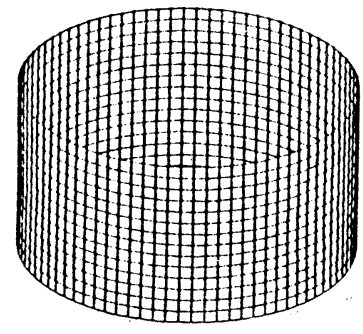

$\delta ; 1=0$

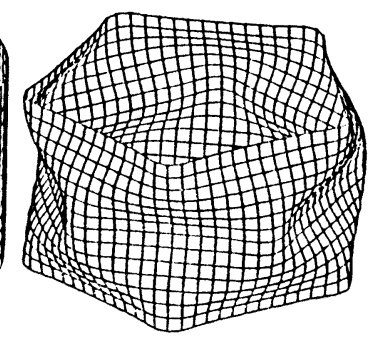

0.073

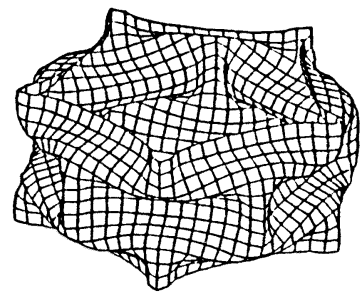

0.298

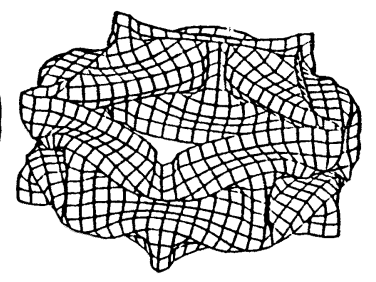

0.119

(c) No. $61(n=5)$

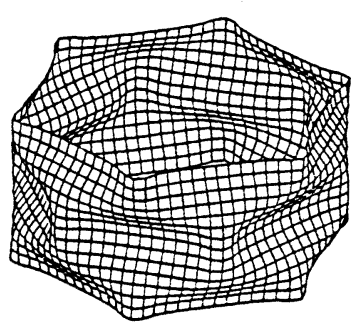

0.100

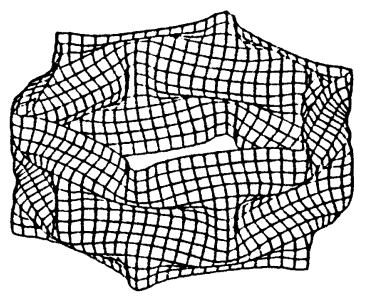

0.230

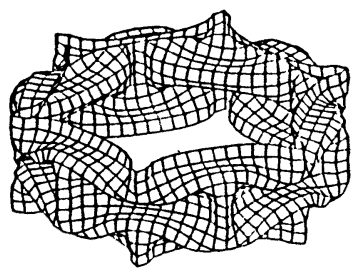

0.111

(d) No. $81(n=6)$

Fig. 11 Calculated crushing processes 
験結果と比較的良好に一致した。

（2）非軸対称圧壊モードにおける周方向波数と半 径・肉厚比の関係については, 著者の一人による従前の 解析結果がほぼ妥当なものであることを確認した。

(3) 平均圧壊応力の実験式としては, Magee らの 公式が実験結果と良好に一致した。

（4）前報で開発した非線形有限要素解析ュードによ り計算した平均圧壊荷重值は, 肉厚の影響が顕著となる 部分を除けば，実験結果と良好に対応しており，既存の 剛塑性理論解析解と比較すると大さく改善された解を与 えた。

（5）同様に, 有限要素解析による王壊変形過程は, 塑性ヒンジラインの移動などを含む実際の複雑な圧壊現 象を忠実に再現した。

なお，今後の課題としては，横荷重による円筒鋼管の 圧壊, 円筒鋼管以外の構造要素の圧壊, 三次元解析, 動 的解析への扗張などを上げることができる。

\section{参考文 献}

1）都井・川井 : 薄肉構造の離散化極限解析（その 5) 一一軸圧縮荷重を受ける円筒殻の非軸対称塑性 座屈モード—, 日本造船学会論文集, 第 154 号 (1983), 353.

2）都井 : 円筒殼の平均圧壊荷重に関する一考察, 日 本造船学会論文集，第 157 号 (1985)， 435.

3）川井・都井・鈴木 : 構造要素の衝突圧壊举動に関 するシミュレーション, 日本造船学会論文集, 第 158 号 (1985), 559.

4）都井・弓削・川井 : 構造要素の衝突圧壊強度に関 する基礎的研究（その 1)——有限要素法による 超大変形圧壊解析一, 日本造船学会論文集, 第 158 号 (1986)， 435.

5) S. P. Timoshenko, J. M. Gere : Theory of Elastic Stability, 2 nd Ed., MaGraw-Hill (1961).

6) G. Gerard : Compressive and Torsional Buckling of Thin Walled Cylinders in the Yield Region, NACA, TN 3726 (1956).
7) S. C. Batterman : Plastic Buckling of Axially Compressed Cylindrical Shells, AIAA J., Vol. 3, No. 2 (1965), 316.

8) L. H. Sobel and S. Z. Newman : Plastic Buckling of Cylindrical Shells under Axial Compression, J. of Pressure Vessel and Technology, Transactions of the ASME, Vol. 102 (1980), 40.

9）川井・都井・弓削：構造要素の一次元塑性座屈シ ミュレーション, シミュレーション(日本シミュ レーション学会誌), 第 5 巻, 第 2 号 (1986), 40 .

10) W. H. Horton, S.C. Bailey and A. M. Edwards: Nonsymmetric Buckle Patterns in Progressive Plastic Buckling, Proc. Soc. Exp. Stress Anal., Vol. 23, No. 2 (1956), 433.

11) Y. Yoshimura: On the Mechanism of Buckling of a Circular Cylindrical Shell under Axial Compression, NACA, TM 1390 (1955).

12）都井・川井 : 薄肉構造の離散化極限解析（その 3)——平板用体要素モデルによる安定問題のシミ ニレーション一, 日本造船学会論文集, 第 152 号 (1982), 441.

13) H. F. Mahmood and A.Paluszny : Axial Collapse of Thin Wall Cylindrical Column, S. A. E. paper, No. 840727 (1984).

14) C. L. Magee and P. H. Thornton : Design Considerations in Energy Absorption by Structural Collapse, S. A.E. paper, No. 780434 (1978).

15) A. Pugsley and M. Macaulay : The Large Scale Crumpling of Thin Cylindrical Col. umns, Quart. J. Mech. and Appl. Math. Vol. 13, Pt. 1 (1960), 1.

16) A. A. Ezra and R. J. Fay : An Assessment of Energy Absorbing Devices for Prospective Use in Aircraft Impact Simulations, Dynamic Response of Structures(ed. by G. Hermann and N. Perrone), Pergamon Press Inc. (1972), 225.

17) W. Johnson, P. D. Soden and S. T. S. Al-Hassani : Inextensional Collapse of Thin-Walled Tubes under Axial Compression, J. of Strain. Analysis, Vol. 12, No. 4 (1977), 317. 